\title{
Review
}

\section{Living a feminist life}

Sarah Ahmed Duke University Press, January 2017, ix+299 pp., ISBN: 9780822363194

Contemporary Political Theory (2019) 18, S125-S128. https://doi.org/10.1057/s41296018-0199-2; published online 13 February 2018

Sarah Ahmed's Living a Feminist Life is much more than a farewell to her institutional academic life in the wake of her highly publicized resignation from Goldsmiths, the University of London, in protest of the university's handling of sexual harassment. Her latest work retains a fierce grip on the spirit of feminist critical theory, while avowing that it is possible and even powerful to 'leave a life' that is not feminist.

It is customary to begin studying feminism by defining it as a 'life question'. For educators, such discussions flow into rewarding 'clicks' of transformative political consciousness when students re-examine their own experiences in the light of feminist theory. Ahmed, writing explicitly for students, begins by considering what it means 'to make everything into something that is questionable' (p. 2), recounting her own 'clicking' moments: 'I began to realize what I already knew: that patriarchal reasoning goes all the way down, to the letter, to the bone' (p. 4). In laying out a foundational self-reflexivity, constantly connecting her background in philosophy (the letter) with her life (bone) as a brown lesbian feminist of mixed heritage, Ahmed shows us how to re-politicize the personal: 'I began to appreciate that theory can do more the closer it gets to the skin' (p. 10).

In urging feminists, 'do not become the master's tool!' (p. 160), Ahmed invokes Audre Lorde's well-known concept of the master's house: 'I had to find ways not to reproduce its grammar in what I said, in what I wrote, in what I did, in who I was' (p. 4). Her own refusal to be a master's tool crops up in, for example, Ahmed's policy of citing feminists of colour rather than white men, because citations 'are the materials through which, from which, we create our dwellings' (p. 16). Feminism's fault lines (such as excluding trans women) show us the cracks in dogmatic certainty: Ahmed argues that a 'feminist tendency ... does not give us a stable ground' (p. 7). Stability mires feminisms in injustice. Instead we must learn to reject what Alexis Shotwell (2016) describes as a politics of 'purity', and instead embrace the idea that feminism's houses may be reconstructed and deconstructed on shifting terrain.

(c) 2018 Macmillan Publishers Ltd., part of Springer Nature. 1470-8914 Contemporary Political Theory Vol. 18, S2, S125-S128 www.palgrave.com/journals 
Ahmed freely acknowledges the difficulty of such work. For her, 'intersectionality is messy and embodied' (p. 119), and feminism creates difficult, 'sweaty concepts' (p. 12). These concepts are expressed with Ahmed's characteristic style of 'turning them this way and that, like an object that catches a different light every time it is turned' (p. 12), producing prismatic rainbows of meaning. In so doing, Ahmed also refuses to separate poetry from politics, affirming, 'I think of feminism as poetry' (p. 12). Language, in order not to become the master's tool, must be recuperated through close scrutiny, through loving litany, through rippling repetitions. Thus, Ahmed repeatedly circles back to her theoretical and literary foremothers - to bell hooks, Audre Lorde, Virginia Woolf, Rita Mae Brown, George Eliot, Toni Morrison, Chandra Talpade Mohanty and Gloria Anzaldúa, to name only a few. In her words, we hear their voices; in her voice, we hear their words - the direct, accessible rigour of hooks, the flowing stream of consciousness of Woolf. In summoning this circle, Ahmed displays the collective power informing her singular voice.

In her classic essay, The Laugh of the Medusa, Hélène Cixous called for an écriture feminine in: 'Write your self. The body must be heard' (Cixous, 1976, p. 880). Now, with growing numbers of women coming forward (\#metoo) to say that their bodies are not being heard, Ahmed's écriture feministe (my twist) takes on even greater relevance. Her writing insists upon embodiment as epistemology: 'feminism begins with sensation', is 'sensible' (p. 21), 'a body that is not at ease in the world; a body that fidgets and moves around' (p. 22). She recalls painful experiences of violence and sexual assault that result in trauma lodged deep in the body. For Ahmed, this violence accompanies every process of gendered assignment, constricting a body that's expected to appear, speak, move and behave in specific ways.

Feminist 'noticing becomes a form of political labour' (p. 32). It is for that reason that the 'feminist killjoy', the one who notices and who names, interrupting the smooth flow of normative traffic, becomes such a central figure. The feminist killjoy must resist the 'promise of happiness' because 'inequality is preserved through the appeal of happiness, the appeal to happiness. It is as if the response to power and violence is or should be to simply adjust or modify how we feel' (p. 60). Ahmed's sister concept of the 'willful subject' is similarly persistent, embodied in the stubbornly raised arm of the 'Willful Child', a grim folktale. The violence that greets any exercise of will necessitates 'a call of arms' (p. 87), the refusal of silence and complicity within the master's house.

Ahmed then invites us to explore diversity work within the master's house of the academy, where the diversity workers themselves often embody lip service paid to policies of inclusion that do not lead to action: 'diversity work is the work we do when we are attempting to transform an institution; and second, diversity work is the work we do when we do not quite inhabit the norms of an institution' (p. 91). Diversity workers are 'institutional killjoys' facing a 'brick wall': 'indeed the wall

S126 (c) 2018 Macmillan Publishers Ltd., part of Springer Nature. 1470-8914 Contemporary Political Theory Vol. 18, S2, S125-S128 
might become all the more apparent, all the more a sign of immobility, the more the institution presents itself as being opened up' (p. 96). To gain any real transformation, Ahmed argues, feminists everywhere must be willful, must push. Again, she acknowledges how exhausting such work can be; how 'institutional passing' (p. 127) may be a survival strategy: 'For those who are not white, whiteness can be experienced as wall: something solid, a body with mass that stops you from getting through ... Heavy, slow, down, brown' (p. 146). To combat such exhaustion, Ahmed calls for solidarity 'to give support to those who are willing to expose the will of the institution as violence; we need to become our own support system ... so that when she speaks up, when she is, as she is, quickly represented as the willful child who deserves her fate, who is beaten because her will is immature and impoverished, she will not be an arm coming up alone; she will not be an arm all on her own' (p. 159).

The anguish that pervades Living a Feminist Life is excruciating; the sorrow and frustration of a woman patiently and gently articulating what it is like to be left all on her own. Perhaps that is why the book is such an intense read - the writer Carin Beilin described her reading as 'like gasping in nettles' (Beilin, 2017). And yet, out of the consequences of being a feminist killjoy, from the pain of leaving a life, comes a moment of 'feminist snap' that Ahmed describes as 'how we collectively acquire tendencies that can allow us to break ties that are damaging as well as to invest in new possibilities' (p. 162). Again, one thinks of the \#metoo movement, the snap of speaking out in multitudes. Movements that only venerate 'strong women' leave little room for the bodies that shatter, the idea that one has been or can be broken. Yet, for Ahmed, there is much to be gained from fragility, 'learn[ing] making from breaking' (p. 169). This is one of her most powerful concepts: that great strength can be derived from shattering experiences: 'From a shattering, a story can be told, one that finds in fragility the source of a connection ... A break can offer another claim to being, being in question as a break in being, recognizing breaking as making a difference in the present, shaping the present' (p. 183). For Ahmed, 'life unfolds from such points' (p. 192). A snap can be an enormous 'relief from [the] pressure' of normative expectations (p. 194). Following her 'snap' from Goldsmiths, Ahmed writes, she has recreated 'feminist hope' and a 'feminist communication system' (p. 211) - Living a Feminist Life appears alongside her blog feministkilljoys.com.

The feminist hope of Living a Feminist Life rests on the power of assembling collectivities, affinities, shelters and survival kits as a 'shared feminist project' (p. 236). Ahmed's 'Killjoy Manifesto' (an instant classic for feminist survival kits everywhere) concludes that 'we must stay unhappy with this world' (p. 254) if we want to change it, must honour our killjoys, our broken spirits and fragile communities if we want to stay strong.

(c) 2018 Macmillan Publishers Ltd., part of Springer Nature. 1470-8914 Contemporary Political Theory $\quad$ Vol. 18, S2, S125-S128 S127 


\section{References}

Beilin, C. (2017) Full Stop. http://www.full-stop.net/2017/02/28/reviews/caren-beilin/living-a-feministlife-sara-ahmed/.

Cixous, H. (1976) The Laugh of the Medusa. Trans. Keith Cohen and Paula Cohen. University of Chicago Press, Signs, vol. 1, no. 4 (summer 1976), pp. 875-893.

Shotwell, A. (2016). Against Purity: Living Ethically in Compromised Times. Minneapolis: University of Minnesota Press.

Aalya Ahmad

Carleton University, Ottawa, ON K1S 5B6, Canada aalya.ahmad@carleton.ca 